\title{
Defense in shallow-water invertebrates at oceanic islands vs. the mainland coast
}

\author{
João Filipe da $\operatorname{Cruz}^{1, *}$, Gonçalo Calado ${ }^{1,2}$ \\ ${ }^{1}$ Faculdade de Ciências Biomédicas, Universidade Lusófona de Humanidades e Tecnologias, Campo Grande, \\ 1749-024 Lisboa, Portugal \\ ${ }^{2}$ IMAR, Departamento de Ciências e Engenharia do Ambiente, Faculdade de Ciências e Tecnologia, \\ Universidade Nova de Lisboa, Campus da Caparica, 2829-516 Caparica, Portugal
}

\begin{abstract}
Islands are often considered natural laboratories and thus excellent models for testing theories on adaptive radiation. To date, most studies have focused on terrestrial ecosystems. In a comparative study between island populations and their mainland counterparts, Vermeij (2004, Frontiers of biogeography, p 239-254), using published data, argued that shallow-water marine shelled molluscs are better defended against predation along continents than on oceanic islands, possibly due to a lower predation pressure on islands. Here we evaluate this hypothesis, using shallow-water marine gastropods from the Azores and the Portuguese mainland as models (the island species Columbella adansoni and the mainland species C. rustica, and populations of Stramonita haemastoma from both study areas). Pleistocene $S$. haemastoma fossils from the Azores were also analyzed. Specimens were measured for defense-related shell characteristics and compared (island vs. mainland populations) using principal component analysis and Mann-Whitney tests. The results revealed that Azorean C. adansoni possess significantly thicker and wider shells with a narrower aperture than mainland C. rustica, which present a lighter shell and a higher spire. Comparisons of island and mainland $S$. haemastoma indicate that the Azorean population is lighter, with a wider aperture, thicker lip, and lower spire. The comparison of Azorean S. haemastoma fossils and extant specimens showed significantly narrower apertures and thicker lips in Pleistocene shells. Despite some evidence supporting the arguments used by Vermeij, our analysis failed to conclusively support this hypothesis as a whole.
\end{abstract}

KEY WORDS: Evolution on islands - Predatory impact - Island biogeography · Columbella adansoni $\cdot$ Columbella rustica $\cdot$ Stramonita haemastoma

\section{INTRODUCTION}

Since Darwin's masterpiece was published (Darwin 1859), islands - and particularly oceanic islands (those not connected to the mainland by continental slopes) - have been considered natural laboratories (Whittaker \& Fernández-Palacios 2007) and are often used as models to test and develop evolutionary theory (e.g. MacArthur \& Wilson 1967, Grant \& Grant 2002, Emerson \& Kolm 2005, Hubbell 2006, Whittaker et al. 2008). Evolutionary biologists have looked to islands as models for adaptive radiation, but have often focused on terrestrial organisms (e.g. Jordan et al. 2003, Grant \& Grant 2006, Losos \& Ricklefs 2009). As pointed out by Vermeij (2004, p. 239), islands are

tidy places for seashore life as well. The water barriers that isolate islands from other lands may work differently for marine species than they do for terrestrial ones but they nonetheless prevent dispersal of shallow-water marine bottom-dwellers to islands, and render marine island ecosystems partially isolated from their counterparts around larger land masses. 
In this context, Vermeij believes that the major difference between terrestrial and marine biota lies in the abundance of high-level predators, which in the sea are little constrained by dispersal. Vermeij formulates a hypothesis, which we will call 'Vermeij's hypothesis', wherein marine shallow-water organisms possess fewer defenses against predators around oceanic islands than along mainland coasts, probably due to lower predatory pressure.

This hypothesis was based on the comparison of structural shell characteristics such as length and projection of the shell spire, thickness of the shell, and size and degree of occlusion of the shell aperture. Vermeij noted that, in general, shallow-water molluscs from oceanic islands had: (1) a higher and more protruding spire, (2) a thinner shell, and (3) a larger and less occluded shell aperture compared to their counterparts on the mainland. These results were interpreted as a reduced defense capacity of island inhabitants, which he suggested to be caused by 'a reduced selection due to predators breaking or entering gastropod shells' (Vermeij 2004) of island species when compared with mainland species. Vermeij (2004) presented 2 factors which support this hypothesis: (1) the low frequencies of repaired injuries on island species, which suggest a lower selection pressure from shellbreaking predators; and (2) the low frequency of gastropod species with labral tooth (a feature which is thought to speed up predation on hardshelled animals) on islands.

Nonetheless, as Vermeij himself wrote, those were preliminary results and 'systematic studies remain to be done'. In fact, the data was collected by different investigators, without the specific purpose of comparing the defenses of island and mainland species, and was mainly referring to South Atlantic and Pacific species.

In the present study, we compared the structural defenses of island and mainland forms of the species Stramonita haemastoma (Linnaeus, 1758), and 2 species of the genus Columbella, existing in the Azores and the Portuguese mainland (Northeast Atlantic).

Even though there is no clear consensus, Stramonita haemastoma can be considered a single taxon with an amphi-Atlantic distribution and a highly variable form (Vermeij 2001, Harding \& Harasewych 2007, Claremont et al. 2011). This predatory whelk with planktonic larvae (Scheltema 1971) preferentially inhabits rocky shores (Rilov et al. 2001, Ramirez et al. 2009), where it preys on animals such as oysters, barnacles, gastropods, and bivalves (Rilov et al. 2004, Lopez et al. 2010).
The genus Columbella has a wide distribution in the East Atlantic region, from the West African coast to the Portuguese coast, and is also found in the Macaronesian archipelagos (Azores, Madeira, Canary Islands, and Cape Verde) (Moolenbeek \& Hoenselaar 1991, Oliverio 1995). The existence of 2 different species in the East Atlantic is recognized: C. rustica (Linnaeus, 1758) and C. adansoni Menke, 1853 (Moolenbeek \& Hoenselaar 1991). The main characteristic that distinguishes both species is the protoconch, which is multispiral in C. adansoni (indicating a planktotrophic life stage) and paucispiral in C. rustica (indicating direct development) (Moolenbeek \& Hoenselaar 1991). The Columbella populations between the Portuguese mainland coast and Senegal are thought to belong to the species C. rustica, whereas the Macaronesian populations (Moolenbeek \& Hoenselaar 1991, Oliverio 1995, Segers et al. 2009), and the populations living south of Senegal (Oliverio 1995), are attributed to the species C. adansoni. These herbivorous species are commonly found in shallow waters, under rocks or in their crevices (Oliverio 1995).

Using both pairs of gastropod species as models, we tested Vermeij's hypothesis, by performing a systematic study comparing the structural defenses of island and mainland species.

\section{MATERIALS AND METHODS}

\section{Study sites}

Since a comparison between species from an oceanic island and from mainland waters was required, the Azores and the Portuguese mainland were selected. Both areas are located at similar latitudes and subject to similar environmental conditions.

\section{Samples}

Adult specimens were gathered by us or with the contribution of several shell-collectors. Island specimens 77 Columbella adansoni and 89 Stramonita haemastoma shells) were collected on São Miguel Island (Azores, Portugal), while their mainland counterparts (100 C. rustica and 79 S. haemastoma shells) were obtained in the Algarve (Portugal). The Pleistocene fossil record of $S$. haemastoma from Santa Maria Island (Azores, Portugal) was also studied (36 specimens, although some were too damaged to allow the measurement of all variables). 


\section{Measurements}

Using a Vernier caliper, shells were measured to the nearest $0.05 \mathrm{~mm}$ for their total length, width, size of the spire (distance between the apex and the suture [in Columbella spp.] or the shoulder [in Stramonita haemastoma], 180 degrees from the aperture), size of the aperture, and shell thickness at the lip (Fig. 1), characteristics which are usually associated with defense. With the exception of the fossilized samples, shell weight was also measured using a scale with a precision of $0.001 \mathrm{~g}$.

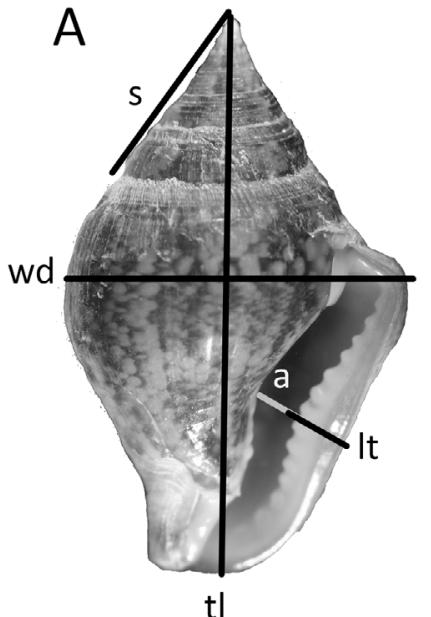

tl

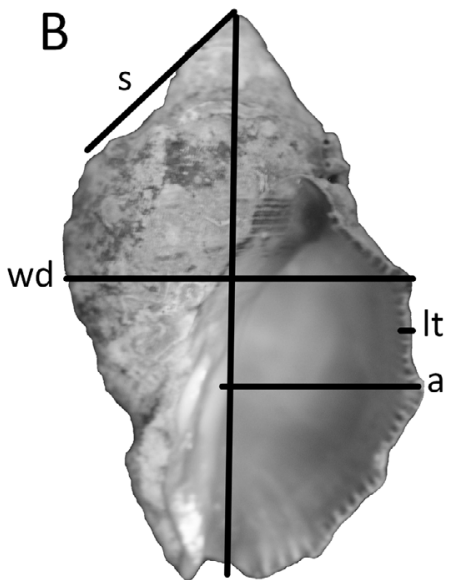

tl
Fig. 1. (A) Columbella spp. and (B) Stramonita haemastoma. Measurement of total length (tl), width (wd), size of the spire (s), size of the aperture (a), and lip thickness (lt)
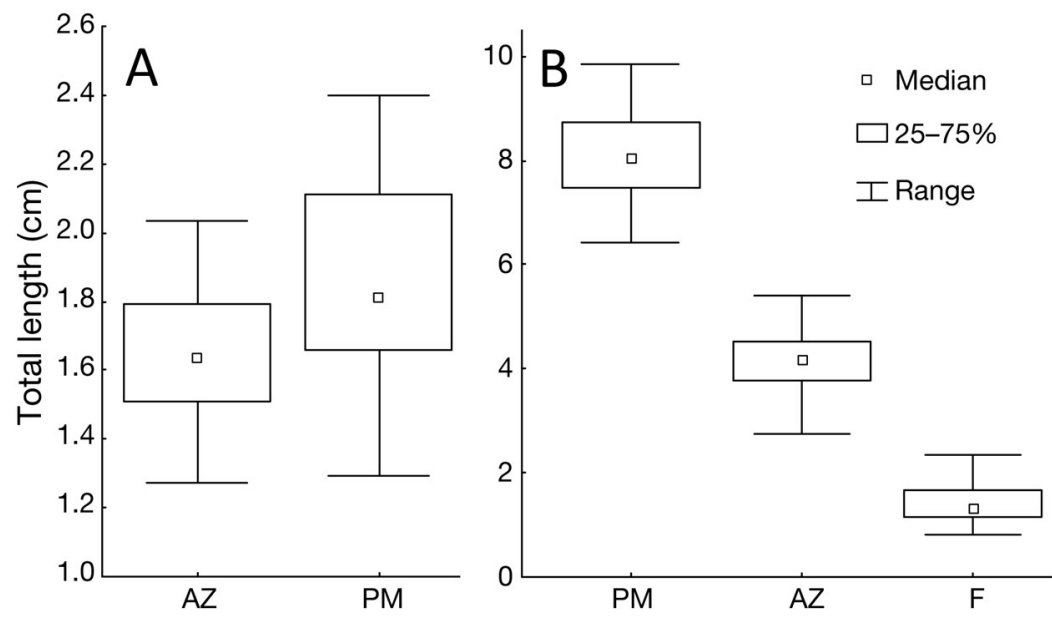

Fig. 2. (A) Columbella spp. and (B) Stramonita haemastoma. Boxplots for total length of samples from the Portuguese mainland (PM) and the Azores (AZ) and S. haemastoma Azorean fossil records (F). The box (25-75\%) is the interquartile range

\section{Statistical analysis}

Parametric approaches were excluded, since neither the original data nor the data transformations met the required assumptions.

To analyze the possibility of allometric growth, measured variables were tested for correlation with total length, using Spearman's correlation test $(\mathrm{p}<$ 0.05). In order to compare individuals of different sizes, variables correlated with total length were divided by it.

Comparisons were made between mainland Columbella rustica and island $C$. adansoni and between mainland and island Stramonita haemastoma. The Azorean fossil record of $S$. haemastoma was also compared with extant Azorean specimens.

Comparison through multivariate analysis was performed using principal component analysis (PCA), which was based on the correlation matrix of the measurements of shell characteristics (corrected for total length), since the variable weight was measured on a different scale.

Variables were compared applying Mann-Whitney tests $(\mathrm{p}<0.05)$ and all statistical analyses were performed using Statistica 7.0 (StatSoft 2004).

\section{RESULTS}

Measurements of both Stramonita haemastoma and Columbella spp. revealed considerable differences in total length between the compared populations (Fig. 2). For both pairs of species, samples from continental Portugal (S. haemastoma: $8.125 \pm 0.783 \mathrm{~cm}[$ mean $\pm \mathrm{SD}] ;$ C. rustica: $1.891 \pm 0.274 \mathrm{~cm})$ were longer than their Azorean counterparts (S. haemastoma: $4.176 \pm 0.571 \mathrm{~cm} ; C$. adansoni: $1.642 \pm 0.183 \mathrm{~cm})$. Spearman's correlation test $(\mathrm{p}<0.05)$ revealed that, for both $C$. adansoni and $C$. rustica, all measured variables were significantly correlated with total length (Table 1). Defensive characteristics of Portuguese mainland $S$. haemastoma shells, along with the Azorean fossil record, also presented significant correlations with total length (Table 1). Extant Azorean $S$. haemastoma samples, however, did not display a significant correlation between total length and lip thickness (Table 1). In view of this and the large 
Table 1. Columbella spp. and Stramonita haemastoma. Spearman's correlation test $(p<0.05)$ between total length and the other characteristics measured. Different sample sizes for Azorean fossils are related to damage of some shells, which did not allow measurement of all variables. ns: not significant; nd: not determined

\begin{tabular}{|lccccc|}
\hline & \multirow{2}{*}{$\begin{array}{c}\text { Columbella spp. } \\
\text { Azores }\end{array}$} & $\begin{array}{c}\text { Portuguese } \\
\text { mainland }\end{array}$ & & \multicolumn{3}{c|}{$\begin{array}{c}\text { Azores haemastoma } \\
\text { Portuguese } \\
\text { mainland } \\
(\mathrm{n}=77)\end{array}$} & $\begin{array}{c}\text { Azorean } \\
\text { fossils }\end{array}$ \\
& $(\mathrm{n}=100)$ & $(\mathrm{n}=89)$ & $(\mathrm{n}=79)$ & \\
\hline Width & 0.925 & 0.911 & 0.948 & 0.891 & $0.976(\mathrm{n}=30)$ \\
Lip thickness & 0.557 & 0.454 & $0.163(\mathrm{~ns})$ & 0.338 & $0.684(\mathrm{n}=23)$ \\
Aperture & 0.662 & 0.962 & 0.935 & 0.902 & $0.937(\mathrm{n}=22)$ \\
Spire & 0.798 & 0.879 & 0.934 & 0.848 & $0.885(\mathrm{n}=36)$ \\
Weight & 0.892 & 0.803 & 0.859 & 0.817 & $\mathrm{nd}$ \\
\hline
\end{tabular}

difference in size between island and mainland specimens, we also corrected lip thickness for total length in order to make it comparable.

\section{PCA}

The results of the PCA indicate that, when corrected for total length, the shell of Azorean Columbella adansoni has a thicker lip and a narrower aperture than that of the Portuguese mainland counterpart C. rustica (Fig. 3). Although there is some overlap between
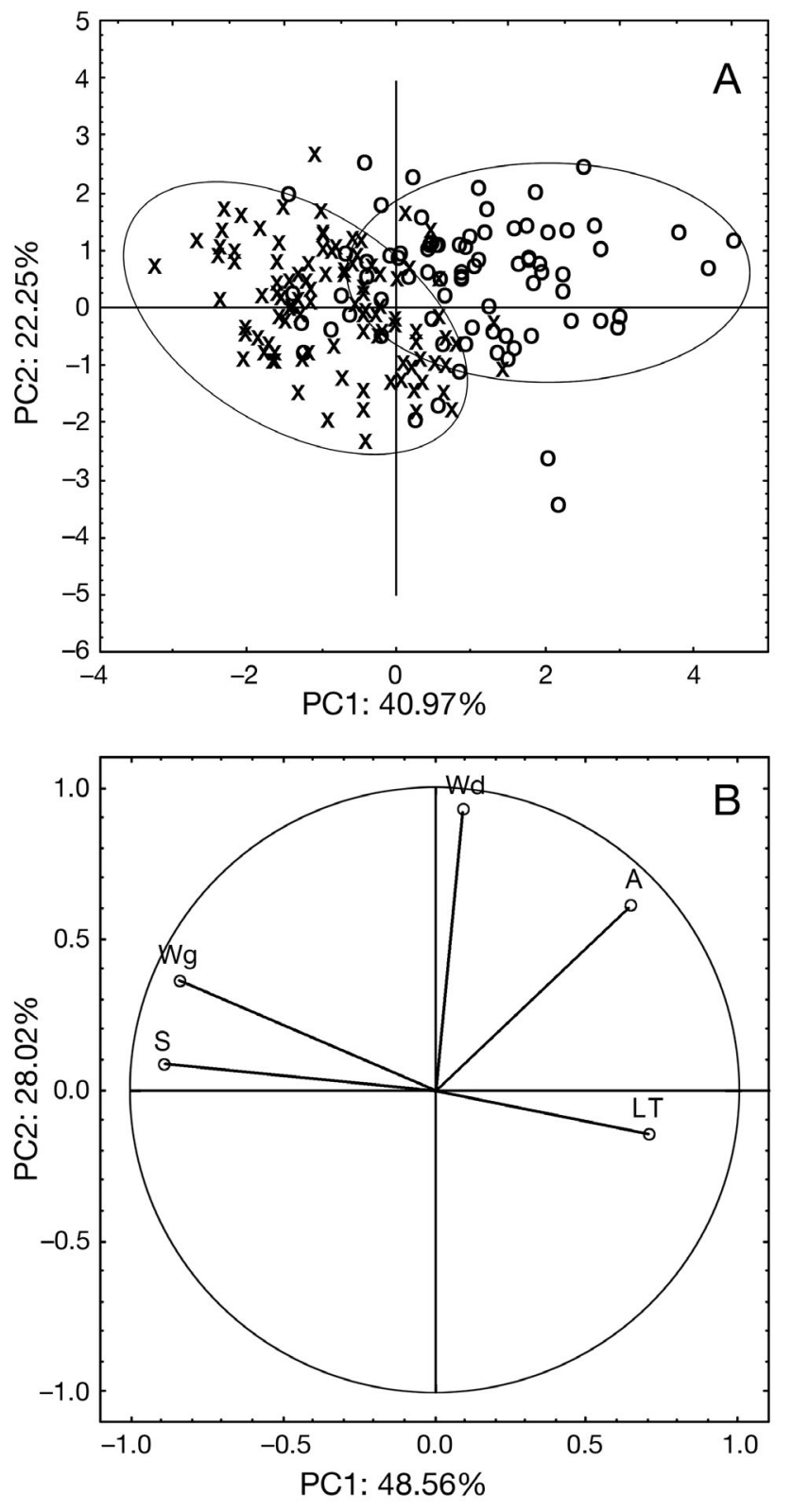
samples, the PCA seems to also indicate a lower spire

The analysis of extant Stramonita haemastoma showed clear differences between both populations (Fig. 4). The results reveal a thicker lip and a wider aperture in the Azorean S. haemastoma, whereas their mainland counterparts are heavier and possess a higher spire.

\section{Comparison of characteristics}

The comparison of characteristics using MannWhitney's test (Table 2) revealed that the Azorean Columbella adansoni shells are wider $(Z=6.436$; $\mathrm{p}<$ 0.05) and present a thicker $\operatorname{lip}(Z=9.657$; p < 0.05) and a narrower shell aperture $(Z=6.001 ; \mathrm{p}<0.05)$ than mainland Portuguese $C$. rustica shells. No significant differences were found when comparing weight $(Z=1.746 ; \mathrm{p}>0.05)$ or size of the spire $(Z=$ $-1.670 ; \mathrm{p}>0.05)$.

For Stramonita haemastoma, Azorean shells are lighter $(Z=-11.712 ; \mathrm{p}<0.05)$, have a lower spire $(Z=$ -10.870 ; $\mathrm{p}<0.05)$, a wider aperture $(Z=5.356$; $\mathrm{p}<$ $0.05)$, and a thicker lip $(Z=8.305 ; \mathrm{p}<0.05)$ than their counterparts from the Portuguese mainland. No significant difference in width was detected $(Z=1.502$; $\mathrm{p}>0.05)$.

The comparison of the Stramonita haemastoma fossil record from Santa Maria Island with extant

Fig. 3. Columbella spp. Principal component analysis for samples from the Azores and Portuguese mainland. PC1 and PC2 explain 40.97 and $22.25 \%$ of the total variance, respectively. (A) Score plot (O: Azores; $\times$ : Portuguese mainland). (B) Loading plot. Variables considered are: width (Wd), lip thickness (LT), spire (S), aperture (A) and weight (Wg) and a heavier shell in the Azorean specimens. 

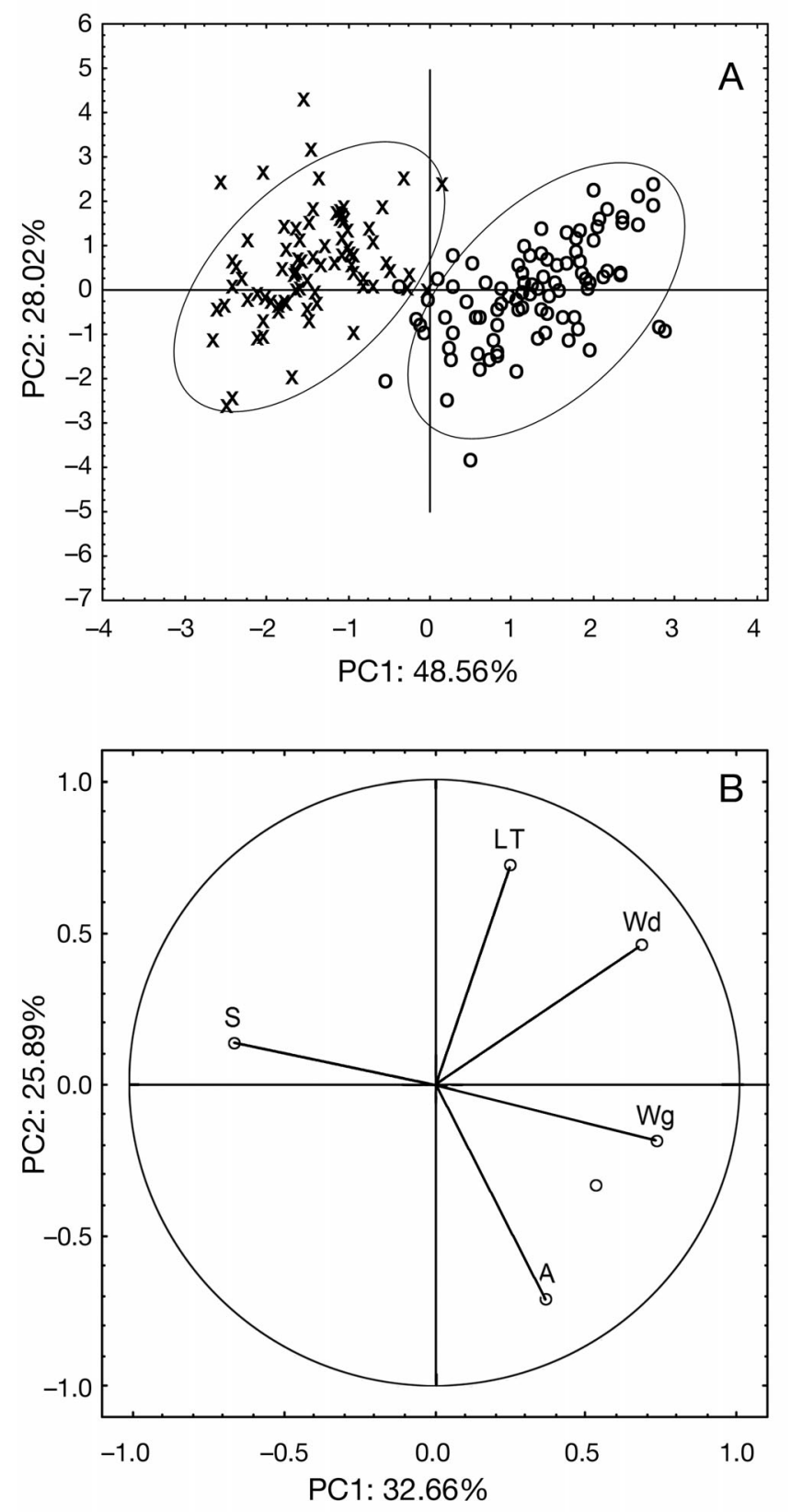

Fig. 4. Stramonita haemastoma. Principal component analysis for samples from the Azores and Portuguese mainland. PC1 and $\mathrm{PC} 2$ explain 48.56 and $28.02 \%$ of the total variance, respectively. (A) Score plot (O: Azores; $\times$ : Portuguese mainland). (B) Loading plot. Variables considered are: width (Wd), lip thickness (LT), spire (S), aperture (A) and weight (Wg)

Azorean shells indicates that Pleistocene specimens had a thicker lip $(Z=3.785 ; \mathrm{p}<0.05)$ and a narrower aperture $(Z=-6.754 ; \mathrm{p}<0.05)$. The comparisons of shell width $(Z=0.532 ; \mathrm{p}>0.05)$ and size of the spire $(Z=0.453 ; \mathrm{p}>0.05)$ did not reveal significant differences.

\section{DISCUSSION}

The hypothesis that marine shallow-water shelled molluscs possess better defenses against predators on mainland coasts than oceanic islands (Vermeij 2004) is not wholly supported by our data, as our results did not reveal better protected shells in mainland specimens.

Assuming that the variables considered in the present study reflect shell protection, the results obtained through the comparison of island and continental populations of Columbella spp. showed a better protection of the Azorean specimens. The shells were wider, with a thicker lip, indicating more robustness and resistance, putatively useful to prevent damage from shell-breaking predators (e.g. ballan wrasse; Figueiredo et al. 2005) or drilling predators (e.g. the muricid gastropods from the genus Ocenebra) (Vermeij 1978). In addition, the narrower aperture found on $C$. adansoni when compared to that of $C$. rustica suggests that putative predators such as octopus (Mather \& Odor 1991) would have more difficulty in entering the shell of the island specimens (Vermeij 1978). To our knowledge, $C$. rustica and $C$. adansoni share the same ecological niche, living under boulders (Oliverio 1995), where they are less exposed to wave action. Thus, differences in shell robustness of Azorean and mainland Portuguese Columbella spp. should not derive from abiotic factors. Nevertheless, we cannot discard the fact that we are comparing 2 different species and that, despite their phylogenetic proximity, the differences 
might be due to species-specific characteristics rather than to selective pressure.

The results of the comparison between Azorean Stramonita haemastoma and its mainland counterpart are ambivalent and require careful attention. According to our data, Azorean muricids tend to have a lower spire and a thicker lip, while mainland specimens are heavier with a narrower aperture. The higher spire and thinner lip of mainland $S$. haemastoma could make this specimen a preferential target for some shell-breaking predators (Zipser \& Vermeij 1978), as the shell is more conspicuous and easier to peel or crush (Vermeij 1978), rendering it less defended than its island counterpart. Even so, the heavier shell of mainland specimens might contribute to a more resistant shell and could be a better measurement for shell robustness than lip thickness in this case, as the lip is the thinnest part of the shell. In addition, the size of the aperture might not be such a relevant feature to $S$. haemastoma defense, since it is usually very large. In fact, as this species inhabits rocky, wave-exposed habitats, differences in size of the aperture may be related to differences in wave action and consequent risk of dislodgment (Rilov et al. 2004). A wider aperture allows a broader foot area and, as a result, a stronger adhesion to the substrate (Trussell et al. 1993, Trussell 1997). Therefore, the broader aperture on islander $S$. haemastoma might be explained by an environmental factor-higher wave actionrather than by lower predatory pressure. These environmental factors might also influence the shorter spire of the island $S$. haemastoma, which reduces the risk of dislodgement by making the shell squatter and, consequently, reducing the exposed area (Rilov et al. 2004). In the well-known littorinid gastropods, the sheltered ecotype (more exposed to predation) has a taller spire than the wave-exposed ecotype (less exposed to predation) (see Johannesson 2003), which seems to support the importance of environmental factors on the size of the spire. Despite all these constraints, the results do not clearly reveal a more protected shell in mainland $S$. haemastoma.

\section{Size matters}

Our results were obtained using data corrected for total length. Notwithstanding this, there was an obvious size difference between samples, with mainland specimens of both species presenting larger sizes than their island counterparts. Differences in size between animals from oceanic islands and continents has been a highly discussed subject (e.g. Foster 1964,
Case 1978, Meiri et al. 2011). Some authors defend the existence of an island rule (sensu Van Valen 1973), wherein species that are smaller on the mainland will tend to reach larger sizes on islands, and vice versa (Lomolino 1985, 2005). Predation, among other agents, is thought to play an important role on these size shifts in insular populations (Palkovacs 2003). When dealing with terrestrial biotas, a lower predatory pressure is generally assumed on islands (e.g. Heaney 1978). Thus, phenotypes that are selected against by predation in mainland populations are more likely to occur on islands.

Several authors suggest that predators such as decapod crustaceans preferentially prey on small molluscs (Juanes 1992, Seed \& Hughes 1995, Smallegange \& Van der Meer 2003, Smallegange et al. 2008). Therefore, the smaller size of island populations might reflect a lower predatory pressure than what exists on the mainland, where smaller individuals are negatively selected. This fits Vermeij's hypothesis: the greater size of mainland specimens might be considered a defensive characteristic, in response to more intense predatory pressure. Notwithstanding this, the differences in size might also reflect a lower growth rate in the Azores, due to a lower productivity likely to occur in oceanic islands (Vermeij 2004).

\section{Clues from the past}

Our results showed a better protected shell in Pleistocene specimens than in extant Azorean Stramonita haemastoma specimens. Although this species has an amphi-Atlantic distribution, recent studies indicate that the most probable source of colonization of the Azores during the Pleistocene was from the Eastern Atlantic (Avila et al. 2009). It is possible that, arriving in an area with a lower predatory pressure (oceanic island) than the center of speciation (mainland), defense-related shell characteristics might have stopped being positively selected. Therefore, this analysis of the Azorean S. haemastoma Pleistocene fossils seems to support an evolutionary trend towards less-defended shells.

\section{Insights on a hypothesis}

The present work represents a systematic study supported by large samples from areas with similar macro-environmental conditions. However, our results do not allow either a generalization or refutation of Vermeij's hypothesis. Despite the obvious impact 
that predator-prey relationships have on organisms' evolution, we cannot discard other variables when trying to understand its importance. Moreover, it is not possible to control all the factors that shape evolution. Besides working with large samples, comparing more populations occupying different ecological niches might be the wiser strategy to overcome such obstacles and unveil these macroevolutionary patterns.

Acknowledgements. We thank the University of the Azores for access to the fossil collection; the shell-collectors José Pedro Borges, Carlos Gonçalves, Pedro Rosa, José Luís Piedade, Gonçalo Rosa, Rui Mendes, and Rita Santiago for access to their private collections; Sasha Vasconcelos for the English review; and the group of reviewers whose contributions have improved this work. This study was developed under the FCT project PTDC/MAR/65854/2006.

\section{LITERATURE CITED}

Avila SP, da Silva CM, Schiebel R, Cecca F, Backeljau T, Martins AMD (2009) How did they get here? The biogeography of the marine molluscs of the Azores. Bull Soc Geol Fr 180:295-307

Case TJ (1978) General explanation for insular body size trends in terrestrial vertebrates. Ecology 59:1-18

> Claremont M, Williams ST, Barraclough TG, Reid DG (2011) The geographic scale of speciation in a marine snail with high dispersal potential. J Biogeogr 38:1016-1032

Darwin C (1859) On the origin of species by means of natural selection, or the preservation of favoured races in the struggle for life. John Murray, London

Emerson BC, Kolm N (2005) Species diversity can drive speciation. Nature 434:1015-1017

Figueiredo M, Morato T, Barreiros JP, Afonso P, Santos RS (2005) Feeding ecology of the white seabream, Diplodus sargus, and the ballan wrasse, Labrus bergylta, in the Azores. Fish Res 75:107-119

Foster JB (1964) Evolution of mammals on islands. Nature 202:234-235

Grant PR, Grant BR (2002) Unpredictable evolution in a 30 year study of Darwin's finches. Science 296:707-711

Grant PR, Grant BR (2006) Evolution of character displacement in Darwin's finches. Science 313:224-226

Harding JM, Harasewych MG (2007) Two new modern records of the Southern oyster drill Stramonita haemastoma floridana (Conrad, 1837) in Chesapeake Bay, USA. Nautilus 121:146-158

- Heaney LR (1978) Island area and body size of insular mammals: evidence from the tri-colored squirrel (Callosciurus prevosti) of Southeast Asia. Evolution 32:29-44

Hubbell SP (2006) Neutral theory and the evolution of ecological equivalence. Ecology 87:1387-1398

> Johannesson K (2003) Evolution in Littorina: ecology matters. J Sea Res 49:107-117

> Jordan S, Simon C, Polhemus D (2003) Molecular systematics and adaptive radiation of Hawaii's endemic damselfly genus Megalagrion (Odonata: Coenagrionidae). Syst Biol 52:89-109
Juanes F (1992) Why do decapod crustaceans prefer smallsized molluscan prey? Mar Ecol Prog Ser 87:239-249

Lomolino MV (1985) Body size of mammals on islands: the island rule reexamined. Am Nat 125:310-316

> Lomolino MV (2005) Body size evolution in insular vertebrates: generality of the island rule. J Biogeogr 32: 1683-1699

Lopez MS, Coutinho R, Ferreira CEL, Rilov G (2010) Predator-prey interactions in a bioinvasion scenario: differential predation by native predators on two exotic rocky intertidal bivalves. Mar Ecol Prog Ser 403:101-112

> Losos JB, Ricklefs RE (2009) Adaptation and diversification on islands. Nature 457:830-836

MacArthur RH, Wilson EO (1967) The theory of island biogeography. Princeton University Press, Princeton, NJ

Mather JA, Odor RK (1991) Foraging strategies and predation risk shape the natural-history of juvenile Octopus vulgaris. Bull Mar Sci 49:256-269

Meiri S, Raia P, Phillimore AB (2011) Slaying dragons: limited evidence for unusual body size evolution on islands. J Biogeogr 38:89-100

Moolenbeek RG, Hoenselaar HJ (1991) On the identity of Columbella rustica from West Africa and the Macaronesian islands. Bull Zool Mus 13:65-70

Oliverio M (1995) Larval development and allozyme variation in the East Atlantic Columbella (Gastropoda, Prosobranchia, Columbellidae). Sci Mar 59:77-86

> Palkovacs EP (2003) Explaining adaptive shifts in body size on islands: a life history approach. Oikos 103:37-44

> Ramirez R, Tuya F, Haroun RJ (2009) Spatial patterns in the population structure of the whelk Stramonita haemastoma (Linnaeus, 1766) (Gastropoda: Muricidae) in the Canarian archipelago (eastern Atlantic). Sci Mar 73: 431-437

> Rilov G, Benayahu Y, Gasith A (2001) Low abundance and skewed population structure of the whelk Stramonita haemastoma along the Israeli Mediterranean coast. Mar Ecol Prog Ser 218:189-202

Rilov G, Benayahu Y, Gasith A (2004) Life on the edge: Do biomechanical and behavioral adaptations to waveexposure correlate with habitat partitioning in predatory whelks? Mar Ecol Prog Ser 282:193-204

> Scheltema RS (1971) Larval dispersal as a means of genetic exchange between geographically separated populations of shallow-water benthic marine gastropods. Biol Bull 140:284-322

Seed R, Hughes RN (1995) Criteria for prey size-selection in molluscivorous crabs with contrasting claw morphologies. J Exp Mar Biol Ecol 193:177-195

Segers W, Swinnen F, de Prins R (2009) Marine molluscs of Madeira: the living marine molluscs of the province of Madeira (Madeira and the Selvagens archipelago). Snoeck Publishers, Heule

Smallegange IM, Van der Meer J (2003) Why do shore crabs not prefer the most profitable mussels? J Anim Ecol 72: 599-607

Smallegange IM, Hidding B, Eppenga JMA, van der Meer J (2008) Optimal foraging and risk of claw damage: How flexible are shore crabs in their prey size selectivity? J Exp Mar Biol Ecol 367:157-163

StatSoft (2004) Statistica (data analysis software system). StatSoft, Tulsa, OK

- Trussell GC (1997) Phenotypic plasticity in the foot size of an intertidal snail. Ecology 78:1033-1048

> Trussell GC, Johnson AS, Rudolph SG, Gilfillan ES (1993) 
Resistance to dislodgement: habitat and size-specific differences in morphology and tenacity in an intertidal snail. Mar Ecol Prog Ser 100:135-144

Van Valen L (1973) Pattern and the balance of nature. Evol Theor 1:31-49

Vermeij GJ (1978) Biogeography and adaptation: patterns of marine life. Harvard University Press, Cambridge, MA

$>$ Vermeij GJ (2001) Distribution, history, and taxonomy of the Thais clade (Gastropoda: Muricidae) in the Neogene of tropical America. J Paleontol 75:697-705

Vermeij GJ (2004) Island life: a view from the sea. In: Lomo-

Editorial responsibility: Francesco Patti,

Naples, Italy lino MV, Heaney LR (eds) Frontiers of biogeography: new directions in the geography of nature. Sinauer Associates, Sunderland, MA, p 239-254

Whittaker RJ, Fernández-Palacios JM (2007) Island biogeography: ecology, evolution, and conservation. Oxford University Press, New York, NY

Whittaker RJ, Triantis KA, Ladle RJ (2008) A general dynamic theory of oceanic island biogeography. J Biogeogr 35:977-994

Zipser E, Vermeij GJ (1978) Crushing behavior of tropical and temperate crabs. J Exp Mar Biol Ecol 31:155-172

Submitted: November 10, 2011; Accepted: January 30 , 2012 Proofs received from author(s): April 22, 2012 